For instance in Hilton's case, ${ }^{1}$ the patient who had first walked on the condyles of her femurs with the legs directed horizontally forward and usually fell asleep sucking one of her own big toes, recovery was complete at the age of twenty-seven years. No doubt the cure in this case would have been much hastened by proper treatment by splints and massage. The immediate canse of the deformity appears to be deficient development of the tendon of the quadriceps extensor. Whether this is primary or secondary to malposition in utero is, like the etiology of the often accompanying club-foot, a disputed question and one which does not much affect treatment. Dr. Taylor and others have noted deficiency of liquor amnii, but on the other hand, hydramnios has often been recorded in such cases. Genu recurvatum is almost invariably present in cases of absence of patella, on which I wrote in THE LANCET of Sept. 25th, 1897. The treatment which I adopted and then described in your columns has generally proved successful in the hands of others as well as myself. It consists in promoting flexion by manipulations and splints and in preventing the recurrence of hyperextension by the latter means. The development of the tendon and of the patella may be encouraged by massage of the front of the knee and thigh. Whether such means would have been successful in such an exceptional case as that described by Mr. Sheild may well be doubted. Probably section of the tendon and capsule as practised by Mr. Fdmund Owen would have been necessary.

It seems likely that this and some other deformities of the knees are much less rare than has been generally supposed and that they have either been overlooked when slight or else were not formerly thought worth recording. Thus as regards absence of the patella, a year ago, when my paper was written, I was only able to find records of 42 caseg, but since that time I have collected notes of five more cases from contemporary medical journals.

I am, Sirs, yours faithfally,

Seymour-street, W., June 11th, 1898. F. MUIBHEAD LITTLE.

\section{A QUESTION OF DIAGNOSIS.}

\section{To the Editors of THE LANCET.}

SiRs,-Recently I was called to see some cases where there was doubt as to the true nature of the disease. There were four children all of whom had sore-throat and one a rash somewhat like a scarlet fever rash but more dusky than it usually appears in that disease. On inspecting the throats I found a limited amount of exadation membrane, but one child had croupous breathing and running at the nostrils. The temperature was not above $102^{\circ} \mathrm{F}$. I considered all the cases to be diphtheritic. The practitioner who called me in - a gentleman of much experience - was of the same opinion and as the patients were all in one small room which was shared by other members of the family he sent the necessary notifications direct to the hospital to ensure their early removal, the townhall being by that time closed for the day. Receiving notice that the medical officer at the hospital had notified these cases as scarlet fever I saw our medical officer of health and told him that I still looked upon them as cases of diphtheria. He told me that one child had since died, the cause of death being given as scarlet fever and "septic" sore-throat, but he could give me no information as to the means which had been taken at the hospital to verify this diagnosis. It has occurred to me that it would be well if in connexion with the sanitary department of every important district there could be facilities afforded for making cultivations of membranes, \&3., so that points of such vital importance might be cleared up without delay. In connexion with this matter and while still in doubt as to the most important part of the case my notification certificates were returned to me with a note solemnly calling $\mathrm{my}$ attention to the fact that I had omitted to fill in the blanks to show whether Mary and John respectively were male or female! $35^{4}$ I am, Sirs, yours faithfully,

Kensington, June 8th, 1898. ALFRED E. BARRETT.

\section{AN URGENT CASE.}

To the Editors of THE LANCET.

SIRS,-We venture to bring a pitiable case to the notice of the medical profession. Mr. James McGregor Laing, a surgeon in the employment of the Coolie Emigration Service,

1 Lectures on Rest and Pain, THr LaYceT, vol. 1i., 1862, p. 497. died in Calcutta on July 6th, 1889, leaving a widow and four children, a girl and three boys, totally unprovided for. Assisted by friends the widow took a boarding-house in Bayswater, but eventually failed to make ends meet. For the last few months she has lived in a small office in 16, Colville-road, W., a tiny place, without fireplace of any kind. The rent of this has been paid up to the end of this month by some generous Freemasons. She has tried to get dressmaking work and has not succeeded in doing so. Since her failure she has had grants of $£ 10$ and $£ 12$ from the British Medical Benevolent Fund, £10 from Grand Lodge, and small amounts from other Masonic lodges. Her children's ages are : the girl fourteen years, the boys twelve, eleven, and nine. The girl is at school, by the kindness of the teachers obtaining tuition without charge. The eldest boy has been elected into the Masonic School but is too ignorant to be admitted, the second is a candidate for Epsom. The boys go to the Westbourne Park Schools at present, helped to do so by the clergy of All Saints, Notting-hill. For a long time the providing of food for these hungry young mouths has been an intense anxiety to the mother; indeed, there actually has not been a sufficient supply of proper nourishment. Mrs. Laing will have to leave her present abode at the end of this month as she has no money to pay the rent.

We can personally guarantee the urgency of this poor lady and are desirous of placing her in a small shop to enable her to gain a living for herself and her children. We strongly recommend the case to the generous consideration of your readers. We shall be glad to receive any subscriptions or offers of help on Mrs. Laing's behalf. We are, Sirs, yours faithfully, J. PiCKETT, M.D. St. And., 26, Colville-square, $W$ Reginald HaRTLEY, M.D. Durh.

June 10th, 1898. 68, Porchester-terrace, $\mathrm{W}$.

\section{THE CATHOLICITY OF THE METRO- POLITAN HOSPITAL SUNDAY FUND. To the Editors of THE LANOWr.}

SIRS,-Referring to your special supplement circulated in the churches on Hospital Sunday, which is an excellent résumé of the position of medical charities, I beg to call your attention to the following statement in the closing sentence of the paragraph on the Prince of Wales's Hospital Fund: "The objects of each fund are the same." You may not be aware of the fact that dispensaries and other medical charities are entirely excluded from any benefit from the Prince of Wales's Hospital Fund; only hospitals pure and simple get grants. The Sunday and Saturday Funds benefit all medical institutions that are willing to conform to certain regulations made by the committee of the funds. I am a director of, and mach interested in, the Marylebone Dis. pensary, 77, Welbeck-street, $W$., and regret to find that this institution is excluded from any benefit from the Prince of Wales's Fand, not being a hospital. I am certain we are losers by this new fund, as subscribers to it, in many cases I know, thought we would get our share at the Marylebone Dispensary and have therefore not given as formerly.

In the interest of charity I think this point ought to be clearly stated in favour of the Sunday Fund as distinct from the Prince of Wales's Fund in all future appeals. I am, Sirs, yours faithfully, Geobgh Cundingham。

Junior Athenæum Club, Piccadilly, W., June 13th, 1898.

\section{THE COMING ELECTION TO THE COUNCIL} OF THE ROYAL COLLEGE OF SURGEONS OF ENGLAND.

To the Editors of THE LANCET.

SIBS,-As the election for the Conncil of the College of Surgeons is approaching it seems reasonable that the electors should know the opinions of those for whom they are to vote. It has been urged that it is undignified for candidates for the Council to canvass for support on account of any special line of policy, as the selection depends rather on their professional eminence. Against this I would say that professional eminence by no means implies sound medical policy, as recent meetings of the General Medical Council have very clearly shown, nor do candidates for any other responsible position expect to be elected without some 